Netradiční pohled V. Slováka na systém větných členů v ruské a české syntaxi, při němž je v naší jazykovědě využita teorie gramatického synkretizmu a současně teorie funkčně sémantických kategorií se strukturou funkčně sémantického pole, je výsledkem snahy přiblížit se objektivní skutečnosti a učinit krok kupředu v syntaktickém bádání nad nejednoznačně řešenými nebo nedořešenými problémy. Jedná se o práci vyzrálou a fundovanou, myšlenkově i obsahově bohatou, kterou lze pokládat za teoretický přínos nejen pro naši současnou jazykovědnou rusistiku. Její obsah je pro výzkum větných členů natolik zásadní, že eventuální další bádání ve sledované oblasti by bez znalosti této monografie bylo nemyslitelné. Díky jasnému a srozumitelnému výkladu může být i při vysoké odbornosti tato práce využívána také ve vysokoškolské pedagogické praxi v rámci studia ruské filologie.

Helena Flídrová

\title{
Literatura:
}

NOSKOVÁ, K.: Olomoucká kolektivní monografie o lingvistickém synkretismu. Opera Slavica, 2017,4 , s. 83-87.

VOBOŘIL, L.: Sinkretizm i polifunkcional'nost'v jazyke. Olomouc: Univerzita Palackého v Olomouci, 2014. ISBN 978-80-244-4004-o.

VOBOŘIL, L., SLOVÁK, V.: Teoretičeskije i prikladnyje aspekty lingvističeskoj sinkretologii. Olomouc: Vydavatelství Univerzity Palackého, 2015. ISBN 978-80-244-4867-1.

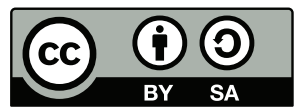

Toto dílo Ize užít v souladu s licenčními podmínkami Creative Commons BY-SA 4.0 International (<https:// creativecommons.org/licenses/by-sa/4.0/legalcode>). Uvedené se nevztahuje na díla či prvky (např. obrazovou či fotografickou dokumentaci), které jsou v díle užity na základě smluvní licence nebo výjimky či omezení príslušných práv.

\section{Про орфоепічну грамотність українців}

ДРУЖИНЕЦЬ, М.Л.: Украӥнське усне мовлення: психо- та соиіофонетичний аспекти. Одеса, 2019. 580 с.

Українську мову здавна вважають однією з наймелодійніших індоєвропейських мов. За евфонічними властивостями їі хтось ставить після французької та перської, хтось порівнює їі з італійською та іспанською. У всякому разі 
у ній немає таких важких для вимови звуків чи звукосполучень як пф (порівн. німецьке das Pferd, der Kopf), тш, кш (пор. польське trzy, krzyk), трш, крш (пор. чеське tři, křik), рдц, лнц, стн (пор. рос. сердце, солнце, властныц̆) та інші, у ній наявні різноманітні чергування (у//в, i//й, же//ж, би//б, ся//сь та низка інших). В українській мові, на відміну від усіх інших слов'янських мов, дзвінкі приголосні зберігають звою дзвінкість у кінці слів та в кінці складів, лише в українській мові переважає асиміляція приголосних за дзвінкістю, за способом творення (уподібнення с-ш, ш-с, т-с, д-з тощо,

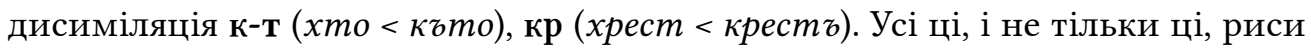
більшою чи меншою мірою відбиті в усному українському мовленні, сприяють високій евфонічності української мови, завдяки чому ії̈ по праву називають милозвучною, музикальною, співучою, солов'їною і под. Саме так оцінювали іiї П’єр Шевальє, фанцуз, який за часів Хмельниччини командував загоном українських козаків, німецький поет Фрідріх Боденштедт, який тривалий час подорожував Україною, російський письменник, перекладач українських пісень, творів Тараса Шевченка Микола Берг, російський учений Ізмаїл Срезневський, відомий російський письменник Лев Толстой, хорватський учений-славіст Ватрослав (Гнат) Ягич, президент Чехо-Словацької Академії наук Зденек Неєдли, югославський учений А. Люкшич, чеський учений Павел-Йозеф Шафарик, засновник сучасної турецької поезї̈ Назим Гікмет Ран, російський радянський поет Володимир Маяковський та інші.

Власне, може, й тому їі всіляко намагалися й намагаються досі принизити, зневажити, поглумитися над нею, назвати їі штучною тощо ті, хто хоче нав’язати Україні чужу мову. Факт загальновідомий, що українська мова впродовж багатьох століть не мала належного і надійного захисту, оскільки не було держави, яка б опікувалася нею, дбала про її розвиток і забезпечувала їй широке функціонування в усіх сферах суспільного життя. Становлення iї фонетичних, орфоепічних та граматичних норм відбувалося у складних дискусіях між представниками західно- та східноукраїнської мовних практик. У Центральній та Східній Україні українська мова до початку XX ст. була заборонена, у Галичині їй не давали розвиватися представники москвофільства, нав’язуючи російську мову чи мовну мішанину під влучною назвою язичіє. Фактично, аж із початку 20-х років XX ст. починається якесь упорядкування мовних норм, кодифікація їх. Однак із початку 30-х років українська мова відчуває неабиякий інтерференційний тиск з боку комуністичної влади та російської мови, яка в російсько-більшовицькій імперії виконувала функцію мови міжнаціонального спілкування. Це домінування російської мови в усіх сферах суспільного життя відчувається й донині, незважаючи на спротив частини української громадськості і навіть на державний статус української 
мови та прийняття Закону «Про забезпечення функціонування української мови як державної».

Шкідливий вплив російської мови на українську відчувається на різних рівнях і передовсім на їі фонетику. Під впливом російської мови українські мовці оглушують дзвінкі приголосні в кінці слів та складів; особливо ріже вухо вимова звука /ф/ на місці українського нескладового /ў/ в словах на зразок читаф, казаф, вофк, шофк, робітникіф, працівникіф тощо; оглушення глоткового (гортанного) /г/ в словах на зразок хори зам. гори, вимахав зам. вимагав, херой зам. герой, слухам зам. слугам і под. або вимова на місці цього світлого дзвінкого українського /г/ проривного задньоязикового / $\mathbf{\Gamma}$ / (багато, гарний тощо); неправомірне пом'якшення африкати /ч/ (ч'ого, ч'ому, ч'оловік, ч’aŭ, ч'ac тощо); спотворена (надто закрита) вимова голосних /е/, /и/ (бе̂зпе̂ре̂чно, нербезпекка, дйтинна, молодчйна, ходйтй та под.).

Тому треба всіляко вітати працю Марії Львівни Дружинець, яка присвячена висвітленню важливих і наболілих для нашої мови і мовлення проблем. Авторка цієї важливої праці дуже переконливо обгрунтувала актуальність обраної теми. Як правильно зазначено в праці, навіть найменші фонетичні зміни «продукують щонайбільші зміни у мовному стрижні, окремі фонологічні інтервенції впливають на характер артикуляційної бази, а отже, за фонетичною своєрідністю криється онтологічна буттєва природа самої мови. Саме тому в сучасних фонетичних студіюваннях на перший план висуваються поняття фонетичного значення, семантики звуків, звуко-кольорових асоціацій, які і створюють своєрідну базу оригінальності і неповторності національної мовної картини світу» (с.9). Дослідження українського усного мовлення у психота соціофонетичному аспектах, як вважає М. Дружинець, дає можливість побачити чинники, які впливають на усне українське мовлення, обгрунтувати шляхи для відповідного внормування орфоепічної системи української мови. В українському мовознавстві є чимало праць, присвячених різним мовним проблемам, зокрема, й правописним, але досі не було грунтовної праці, яка б глобально виявила й описала усне українське мовлення, визначила норми вимови голосних і приголосних звуків у різних позиціях, відхилення від цих норм, причини цих відхилень, інтерференційні моменти тощо. Тому й актуальність теми, і наукова цінність праці не викликають жодного сумніву.

У Вступі до книжки авторка відповідно й сформулювала мету праці: обгрунтувати нормативність та історичну органічність орфоепічної системи українського усного мовлення в діахронії (від перших писемних пам'яток) та синхронії у її проекції на національну специфіку звукової системи української мови. Для досягнення мети визначила основні завдання, зокрема: узагальнити теоретичні засади й аспекти вивчення українського усного мовлення; 
схарактеризувати орфоепічну нормативну базу сучасного українського усного мовлення; представити їі діахронічну ретроспективу, простеживши історичне коріння кожної орфоепічної норми в писемних пам'ятках; описати девіантні та деградаційні процеси в орфоепічній системі сучасного українського усного мовлення та запропонувати шляхи підвищення рівня вимовної культури в національному лінгвосоціумі; на основі соцопитування проаналізувати орфоепічний рівень мовлення українських респондентів на теренах України та за їі межами, виокремивши девіації і навіть гендерну специфіку; укласти орфоепічний стандарт (з електронним носієм); спрогнозувати прогресивні лінії розвитку сучасної української орфоепії та цілу низку інших. Наперед забігаючи, зазначмо, що всі завдання, які визначила для себе авторка, успішно виконані, завдяки чому й тему повністю розкрито.

Треба відзначити й належно продуману, доцільну структуру самої праці. Складається вона зі Вступу, чотирьох розділів, багатьох підрозділів до кожного з них, Висновків, списку використаної літератури та цілої низки додатків. У кожному з розділів чи підрозділів подано детальний опис того чи іншого питання.

Перший розділ - «Теоретичні засади вивчення українського усного мовлення» - присвячено описові специфіки й актуальних аспектів дослідження українського усного мовлення, наведено десятки визначень різних авторів, що таке орфоепія, схарактеризовано етапи формування орфоепічних норм. Усякого схвалення заслуговує погляд М. Дружинець на періодизацію української мови, яка, уточнюючи Ю. Шевельова (виділяє ще окремі підперіоди), вважає, що протоукраїнська мова виникла в VII і тривала до X ст., в XI - першій половині XIV ст. існувала вже давньоукраїнська мова (а не якийсь там «древнєчи общєрусскій язик» («вібчоруська» мова, за жартівливим визначенням Ю. Шевельова), як це намагалися нав’язати з шовіністичних позицій українцям і взагалі - вченій громадськості російсько-московські ідеологи та вчені. Далі староукраїнська мова (друга половина XIV - перша половина XVII ст.) і нова українська мова (друга половина XVII ст. - наш час).

Відзначмо, що першим голосно заявив про те, що українська мова сягає своїм корінням праслов'янської мови, тобто походить саме від неї, український галицько-буковинський учений Степан Смаль-Стоцький, за що потім піддавався гострій критиці з боку О. Шахматова та інших, отримав ярлик українського буржуазного націоналіста. Звичайно, що Смаль-Стоцького підтримували й інші українські вчені, і про це все згадано у рецензованій праці.

Перший розділ вважаю взагалі дуже цінним, оскільки в ньому показано, проаналізовано основні характерні риси української мови, які зародилися ще в надрах праслов'янської мови. Далі авторка поступово, дотримуючись 
хронології, підтверджує існування цих особливостей української мови наявністю їх у друкованих пам'ятках давньоукраїнської, староукраїнської, а потім уже нової української мови. Ці питання розглядаються у підрозділах першого розділу («Відбиття особливостей української народної вимови у пам'ятках давньоукраїнської літературної мови»; «Відбиття особливостей української народної вимови у пам'ятках староукраїнської та нової доби» тощо). У цьому ж розділі описано шляхи становлення орфоепічних норм, перелічено ці основні правила, показано відхилення від них («Девіантні та деградаційні процеси сучасного українського усного мовлення»).

Не менш важливими є й інші розділи дисертації. У другому - «Українське усне мовлення: психолінгвістичний аспект» - йдеться про фонетичний зміст та кольорові асоціації звуків української мови в залежності від їхніх класифікаційних ознак - ряду, піднесення, лабіалізованості (для голосних) та акустично-артикуляційних ознак - участі голосу і шуму, місця творення, способу творення, м’якості/твердості - для приголосних. Тут порівняно також семантику українських та польських сонорних звуків, їхні кольорові характеристики. Побіжно порівнюються факти й з російськими звуками, але цьому порівнянню, на нашу думку, варто було приділити більше уваги, оскільки українське мовлення, як про це вже йшлося, перебуває в полі дуже сильного впливу російського. Загалом, це цікаве дослідження, яке показує, якими з десяти ознак мовці характеризують асоціативно ті чи інші звуки. Щоправда, трохи здивувало, що мовці майже суцільно ігнорують або характеризують негативно глотковий звук [г]. Я його назвав би легким, світлим, навіть сонорним, до речі, я так і назвав його світлим на початку своєї рецензії, ще навіть не опрацьовуючи другий розділ цієї праці. Його чомусь характеризують як малий, грубий, темний, слабкий, сумний, злий. Можливо, тому, що над мовцями, які брали участь в анкетуванні, тяжить російська мова? У російській немає цього звука. В українських та в словах із інших мов російськомовні особи оглушують його (ось, звідки Хельсінкі, Бетховен, хіт-парад, хот-дог, секонд-хенд та інші подібні). У польській мові теж його майже не відрізняють від [x], тобто вимовляють з оглушенням. Вважаю, що глотковий чистий, неоглушений звук [г] - це одна з гарних ознак української мови (подібно його вимовляють лише в білоруській, чеській та словацькій мовах).

У третьому розділі - «Соціофонетичний опис українського усного мовлення: голосні та приголосні звуки» - проаналізовано типові орфоепічні помилки (девіації), які трапляються не тільки в звичайних мовців, але й у респондентів, з якими проводилося соцопитування на теренах України та за їі межами, простежено вимову голосних і приголосних звуків за писемними 
пам'ятками кінця XVIII-XIX ст., проведено соціофонетичний опис вимови українських голосних та приголосних звуків на сучасному етапі, описано вимову ненаголошених голосних звуків [e], [и], звуків [о], [i], дзвінких, глухих, сонорних приголосних, африкат та префіксів перед глухими звуками тощо.

Аналогічним до третього є і четвертий розділ, тільки в ньому проведено соціофонетичний опис різних звукосполук, зокрема, вимову звукокомплексів свистячі в пре- та постпозиціях, шиплячі в таких самих умовах, вимову свистячих звуків перед шиплячими та навпаки, гендерні особливості сучасного мовлення українців тощо.

Завершується праця, як і прийнято, глибокими й доборе продуманими висновками.

Треба відзначити дуже уважне й глибоке опрацювання автором праці матеріалу дослідження, докладний опис того чи іншого питання. Без перебільшення можна стверджувати, що в українську мовознавчу науку уже давно прийшла, а тепер це солідно підтвердила своєю вагомою, скрупульозною працею дуже серйозна дослідниця, яка зуміла описати надзвичайно важливу тему українського мовознавства - становлення орфоепічних норм української мови від найдавніших часів до нашого часу.

Робота написана добрим науковим стилем, сприймається легко, кожне положення глибоко аргументоване, підтверджене належними прикладами. До позитивних моментів дисертації можна віднести й те, що вона не переобтяжена іншомовною термінологією, як це часто можна спостерігати в деяких кандидатських дисертаціях, статтях молодих, переважно, науковців, тобто ця праця, монографія буде доступна не тільки для фахівців, але й для широкого читача, а отже, сприятиме зростанню культури усного українського мовлення.

Можна позаздрити працьовитості дисертантки не тільки в опрацюванні теми, перечитуванні сотень наукових праць, дотичних до їі теми, умілій i доцільній цитації їх для підтвердження чи заперечення своїх думок і висновків, але і їі скрупульозності в технічному оформленні праці. Попри якісь окремі помилки, описки тощо комп'ютерний набір роботи викликає приємне враження, адже розставляння різноманітних діакритичних знаків та позначок у транскрипційних записах матеріалу вимагало неабиякої уваги, нервів і посидючості.

Вважаємо, що українська мовознавча наука отримала у формі монографиї Марії Дружинець «Українське усне мовлення: психо- та соціофонетичний аспекти» вагому і важливу працю. Тепер як ніколи потрібна ця праця. На українську мову спілкування переходять (дехто з необхідності, службового 
обов’язку, дехто з усвідомлення, що пора повертатися до рідних коренів і рідної мови) все ширші маси російськомовного населення, особливо журналісти, політики, державні службовці та інші категорії мешканців України. Але, переходячи на спілкування українською мовою, вони разом з тим привносять до неї, до її усного мовлення російську практику вимови окремих звуків і цим завдають неабиякої шкоди орфоепічним нормам української мови.

Усілякого схвалення заслуговують 9 додатків до книги, у яких наведені різноманітні приклади вимови окремих звуків чи звукосполук у різних позиціях, а також укладений авторкою «Орфоепічний стандарт української мови (з електронним носієм)», тобто із звуковою копією цих записів, які забезпечать фіксацію зразків мовлення як зоровою, так і слуховою пам'яттю. В українському мовознавстві, на жаль, до цього часу не було єдиного українського орфоепічного кодексу, яким би користувались українці в світі й у якому б пропонувалися деталізовані, чіткі норми вимови звуків та звукосполучень у різних позиціях. Тепер таке джерело інформації є.

У короткій рецензії неможливо окреслити всі цінності, позитивні моменти дисертації, але можна з певністю сподіватися, що ця праця Марії Дружинець увійде в число кращих українських мовознавчих праць. Треба віддати належне: у цю працю вкладено немало часу і зусиль.

На завершення ще раз повторимо, що в рецензованій праці, у додатках до неї охоплені, описані й оцінені всі важливі моменти, які стосуються культури усного українського мовлення.

Хотілося висловити й деякі зауваження. На мій погляд, деякі питання треба було особливо підкреслити. Як уже про це йшлося на початку, в сучасному українському мовленні сильної деформації зазнає гортанний (глотковий) звук [г], причому його частіше спотворюють не звичайні мовці, бо українцеві закладено генетично вимовляти його чисто, без оглушення, а російськомовні в побуті в переважній більшості диктори радіо і телебачення, актори театрів і кіно, які вважають, що саме так він і повинен звучати. Це саме стосується й шиплячої африкати [ч]. В українській мові шиплячі стверділи, причому давно, пом'якшено вони вимовляються лише перед [i] та коли подовжені (піддашщя, клоччя, збіжжя), і про це в дисертації мовиться. Але в російській мові цей звук зберіг давню м'якість, і під впливом російської його пом'якшують українські мовці. Це, як і в випадку з гортанним [г], своєрідний гіперизм: дехто думає, що так правильно, що так і треба вимовляти. I ще одне. У зразках правильної вимови (в додатках) подібні приклади наведені (на зразок воукк, поўниц̆, читац̆, сліў, студентіц̆), але треба було таки наголосити на цьому спеціально, що білабіальний [w] вимовляємо, не стулюючи губ, бо під впливом російської мови оглушення його і вимова як [ф] дуже поширена. 
Друге, що викликає сумнів, це твердження, правда, це твердження не М. Дружинець, вона тільки констатує, що нібито в українському мовленні в словах іншомовного походження трапляються напівпом'якшені губні, задньоязиковий [к] та фарингальний [г] перед голосними [a], [у] (граф. я, ю): бюро, пюре, фюзеляж, мюзикл, Кяхта, гяур, кювет, гюйс). Тут авторка посилається на посібник Сучасна українська мова 1993, с. 63 за редакцією А. Грищенка. Зрештою, можна посилатися на будь-який підручник, оскільки вони всі повторюють це твердження. Тут знову пішли за російськими джерелами. У російській мові кажуть n'am', n’аний, В'ачеслаф, б’ypo, n'ynuтр і под. але українець вимовляє губні чи інші приголосні твердо, а після них [j]. Як можна пом'якшити глотковий $[г]$ в словах Гюго, гяур? Чи є різниця у вимові слів б’ю, n’ю і бюджет, пюре? Яка різниця між словами комп'ютер і пюпітр? Хіба ми не однаково вимовляємо? А пишемо по-різному, бо так по-різному пишуть у російській мові. Я очікував, що в новому правописі внесуть зміни щодо написання апострофа в іншомовних словах, навіть посилав свої пропозиції, але ми (не ми, а наше Міністерство освіти і науки) далі дотримуємося російського правопису і російської вимови. Про новий правопис узагалі гірко говорити, бо шуму було багато, а результату мало.

Десь трапляються якісь описки. Замість XI ст. написано XIX, назву польського містечка Тусhу перекладено як Тичи (відомо, що буквосполучення ch по-різному читається в різних мовах. В англійській - це ч, у французькій ш, у німецькій, польській, чеській, словацькій - х), у прізвищах польських учених Lehr-Splawiński, Urbańczyk використана чеська літера на позначення м'якого н', але це аж ніяк не впливає на високу якість і наукову цінність цієї важливої праці. Навряд, чи комусь вдалося б написати таку велику і серйозну працю, не припустившись якихось дрібних неточностей та описок.

Ще раз хочу відзначити, що мав неабияку приємність, читаючи працю Марії Дружинець «Українське усне мовлення: психо- та соціофонетичний аспекти». Шкода, що вийшла вона невеликим накладом, бо така праця мала би бути під руками у кожної людини, яка користується українською мовою, у кожного викладача вищого чи середнього навчального закладу, в учителя, у працівників радіо і телебачення, політиків, державних чиновників, акторів і в усіх, хто не байдужий до рідної мови. 


\section{Література:}

DRUŽYNEC', M.L.: Ukrajins'ke usne movlennja: psycho- ta sociofonetyčnyj aspekty. Odesa, 2019. $580 \mathrm{~s}$.

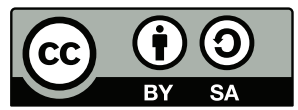

This work can be used in accordance with the Creative Commons BY-SA 4.0 International license terms and conditions (<https://creativecommons.org/licenses/by-sa/4.0/legalcode>). This does not apply to works or elements (such as images or photographs) that are used in the work under a contractual license or exception or limitation to relevant rights.

https://doi.org/10.5817/OS2021-2-9

\section{Регионы России в парадигме антропоцентризма, лингвокультурологии и культурной географии}

CINGEROVÁ, N. - DULEBOVÁ, I.: Kultúrne regióny Ruska. Bratislava: Univerzita Komenského v Bratislave, 2021. 200 s. ISBN 978-80-223-5113-3.

В рецензируемом нами вузовском учебнике Kultúrne regióny Ruska, написанном в рамках грантового проекта KEGA 052UK-4/2018: Vysokoškolská učebnica Kultúrne regióny Ruska v cestovnom ruchu - Н. Цингерова, - кандидат филологических наук, доцент кафедры русистики и восточноевропейских исследований Философского факультета Университета им. Коменского в Братиславе, вместе с соавтором И. Дулебовой, кандидатом филологических наук, доцентом из одноимённой кафедры, предлагают вниманию студентов и более широкой научной общественности новый вузовский учебник, затрагивающий проблематику культурных регионов России. Цель авторов - предложить подходящий материал не только для учебных программ словацких вузов, специализирующихся на туризме и восточнославянских исследованиях, но также и для будущих учителей, преподавателей и переводчиков. В своём учебнике авторы представляют учебный материал на основе своих лекций и семинаров со студентами в стенах Университета им. Коменского в Братиславе. Считая региональный аспект самым важным, замыслом Н. Цингеровой и И. Дулебовой является более комплексный взгляд на существенную специфику разнообразных образов России и судьбы её регионов. Положительно оцениваем тот факт, что авторы своё внимание не сосредоточивают только на двух наиболее известных «столицах». Контекстуализацией исторических и культурных 